\title{
The Caspian Language of Šahmirzād
}

\author{
HABIB BORJIAN \\ COLUMBIA UNIVERSITY
}

\begin{abstract}
Located in the Semnān area (midway between Tehran and Khorasan), the town of Šahmirzād and its neighboring villages are home to speakers of Šahmirzādi, a vernacular sharply differing from the other language types spoken in the Semnān area but closely related to the Mazandarani language spoken across the Alborz range to the north, along the Caspian coast. This article studies Šahmirzādi phonology, grammar, and vocabulary, with a look at cross-linguistic influence in the situation of language contact. The article concludes with a discussion of the possible status of Šahmirzādi as a separate language within the Caspian family.
\end{abstract}

\section{INTRODUCTION}

The township of Šahmirzād (locally Šâmerzâ) sprawls along the southern slopes of the Alborz range, 15 miles north of Semnān, at $35.8^{\circ}$ north latitude, $53.3^{\circ}$ east longitude, and 2,000 meters above sea level. Two parallel mountain ridges separate Šahmirzād, which is in the Semnān district, from Dodānga and Savādkuh districts of the Mazandaran (Māzandarān) province. Downslope from Šahmirzād lie Sangesar and Semnān, each with its distinct Iranian language, forming a Sprachbund with the nearby Sorxa'i, Lāsgerdi, and Aftari, all of which are crowded into the district of Semnān. The permanent population of the township of Šahmirzād, recorded as 7,273 individuals in the 2006 and 8,882 in 2011 censuses, swells significantly in summers upon the return of the residents who work elsewhere. The villages located in the valleys on the north of Šahmirzād, including Deh Șufiān, Āserān, Jāšm, and Garm Čašma, speak varieties of Šahmirzādi. See Figure $1 .{ }^{1}$ The local residents estimate the total number of speakers of Šahmirzādi to be around 5,000 individuals.

\subsection{Documentation}

Documentation of Šahmirzādi was begun in the 1880s by Valentin Žukovskij (henceforth Žuk.), who elicited from Persian short texts and anecdotes and a list of words and verb paradigms (Žukovskij 1922: 5-8 and glossary). This was followed by compilation of basic morphology along with two short texts by Arthur Christensen (henceforth Chris.; 1935: 142-78), ${ }^{2}$ brief notes by Georg Morgenstierne (henceforth Morgen.; 1960: 108-9), a comparative lexicon with other languages of Semnān by Manučehr Sotuda (henceforth Sotu.; 1963), an elicited text by Irān Kalbāsi (henceforth Kalb.; 2009: 531-33), and a typological study by Mohammad Dabir-Moqaddam (henceforth Dabir.; 2014: vol. II, 1034-90). The unpublished materials consulted in this study include a list of words and sentences from the 1960s collected by Hušang Purkarim (henceforth Pur.), kindly shared by a colleague of his

The author would like to thank Erik Anonby for his meticulous review of the section on phonology, and Daniel Kaufman and Daniel A. Barry for their insights on the phonetics of the recorded data. I am also indebted to the anonymous reviewer for many comments and insights.

1. To the southwest of Semnān, in the Garmsār area, the village of Farvān has an outlier Mazandarani dialect of Šahmirzādi type. See Borjian 2013b.

2. Examples are cited from Christensen (pp. 171-75), unless otherwise noted. 


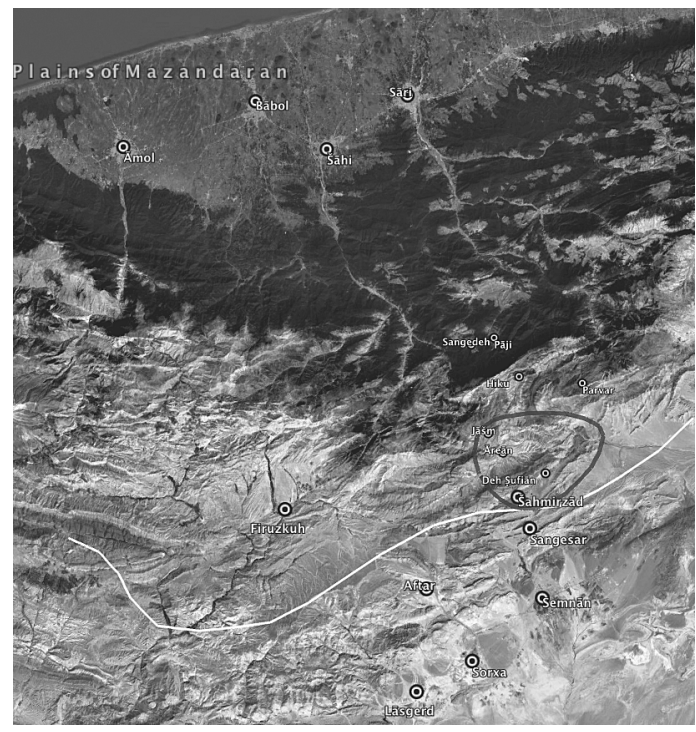

Fig. 1. Map of Semnān and central-eastern Mazandaran. The white line delineates the Caspian linguistic zone on the north. The dark ring marks the extent of Šahmirzādi. The satellite map is from Google Earth.

who preferred to stay anonymous; audio recordings in 2003 of a 227 -item basic vocabulary, shared generously by Alexander Kolbitsch; and the present author's unpublished documentation (since 2009), which is left unmarked in the citations that follow.

In this study I have chosen to draw upon all these credible sources rather than eliminating past knowledge in favor of my own field notes. In view of the incessant weakening of the local idioms under the pressure of Persian, I believe that no reasonable documentation should be ignored with the pretext that the methodologies used in the past are incompatible with current practice. Multiplicity of sources surely adds to the richness of language description even if the job becomes more complicated.

The materials at hand, being from multiple sources, show considerable variance in transcription; for instance, the gloss 'eye' is elicited by Žukovskij as čašm, by Christensen as

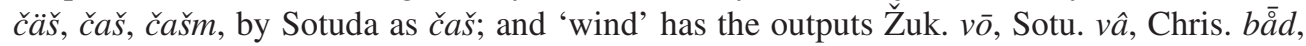
and my field-notes [va']. ${ }^{3}$ In Christensen's documentation, it is evident that the speech of his chief informant is strongly persianized, marking phonology (barf, barg, bìd, bist, which are $v$-initial words in other sources), morphology (verb personal endings, §4.4), and syntax (adpositions, §3.4); these discrepancies could partly be due to infected idiolects of seasonal workers who winter in Mazandaran and elsewhere. Note that the phoneme /â/ (§2.2.2) is

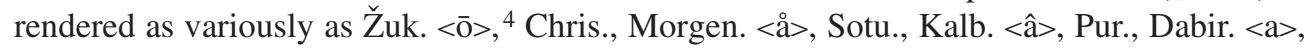
while /a/ (\$2.2.7) is rendered in the latter two sources as $<\mathfrak{x}>$. The original symbols are

3. For more comparisons, see Rastorgueva and Edel'man 1982: 475-80.

4. Žukovskij tends to transcribe back low vowels with symbols that suggest mid rather than low place of articulation. 
Table 1. Vowel Phonemes and Allophones

\begin{tabular}{lll}
\hline \hline & Front & Back \\
\hline High & $/ \mathrm{i} /[\mathrm{i}]$ & $/ \mathrm{u} /[\mathrm{u}, \mathrm{u}, \mathrm{r}]$ \\
Mid & $/ \mathrm{e} /[\mathrm{e}, \mathrm{r}]$ & $/ \mathrm{ö} /[\mathrm{o}, \mathrm{v}, \mathrm{e}]$ \\
& $/ \varepsilon /[\varepsilon, \mathrm{s}$, ə] $]$ & \\
Low & $/ \mathrm{a} /[\mathrm{a}, \mathfrak{x}, \mathrm{e}]$ & $/ \mathrm{a} /[\mathrm{a}, \mathrm{p}]$ \\
\hline
\end{tabular}

retained in the citations below. I decided to stay loyal to transcription symbols from the original sources, although it may introduce an additional level of complexity.

\section{PHONOLOGY}

2.1. Consonants. The consonantal inventory of Šahmirzādi is /p b t d k g č j f v s z š ž x $\gamma \mathrm{h} \mathrm{m} \mathrm{n} \mathrm{r} \mathrm{l} \mathrm{y/.}$

2.1.1. The phonemic value of $\check{z}$ [3] is to be verified; its presence in my notes is limited to každöm [kæz'dø'm] 'scorpion' and hižda [hiz'dæ] 'eighteen'. As in Mazandarani proper, the existence of $\check{z}$ therefore appears to be limited to regressive assimilation of the phoneme $/ \mathrm{j} /$ [d3] before $/ \mathrm{d} /$.

2.1.2. Dorsals. The articulations of $/ \mathrm{k} /$ and $/ \mathrm{g} /$ are not exclusively velar as is the case in Mazandarani; younger speakers tend to follow the Persian model of palatalizing before front vowels; thus, gal 'throat' is heard as both [gæl] and [łæl]. Likewise, the prevalent Persian way of switching between back velar/uvular fricative and stop ([6] and [G] in most speakers) is also the norm in Šahmirzādi, contrary to Mazandarani, in which these sounds have collapsed to voiced velar fricative [в] in all positions. This study employs both $\gamma$ and $q$,

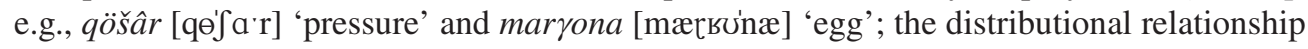
between these allophones can only be established with sufficient data.

2.2. Vowels. This section proposes the Šahmirzādi vowel inventory as /â a $\varepsilon$ e i ü ö/. These phonemes are arranged together with their phonetic realizations in Table 1 . The choice to include the fronted allophones as basic for the phonemes / $\ddot{\mathrm{u}} /$ and /ö/ is made due to their higher occurrences (\$2.2.8), although this choice leads to an asymmetrical phonemic inventory. The sections that follow present a detailed analysis of each vowel sound and its considerable variation among speakers. Variations are mostly due to different speakers, but they may also be the perception of different listeners to the same audiotapes.

2.2.1. Vowel length. Although Middle Iranian length distinction has not reached Šahmirzādi systematically, /â u i e/ are perceivably articulated long when compared to other vowel sounds. Besides, as in Persian, slight lengthening precedes consonant clusters in coda, as in $a b r$ [æ'br] 'cloud', valg [væ'lg] 'leaf'. The lengthening in rassn [ræ'scn] 'rope' and

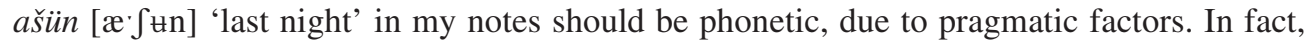
vowel lengthening in initial syllables is common in many parts of Iran.

2.2.2. /â/ is realized as [a], sometimes partially rounded to [p], and is usually articulated half long: [a't3̧]] 'fire', [t $\int a^{\prime}$ 'kæ] 'river', [ma'r] 'mother', [dømdæ'ra z] 'snake', [va'] 'wind',

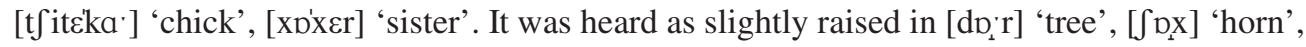

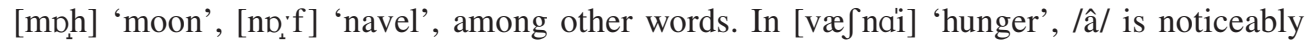
short, compared with [væJ'na'] 'hungry'. It is therefore hard to judge whether the position in stressed vs. unstressed syllables imposes a condition in this phonetic variation. More data is needed to establish free vs. conditional variation for this phoneme. 
2.2.3. /i/ is half long or long, especially in final position: [di'] 'smoke', [tali:] 'rock',

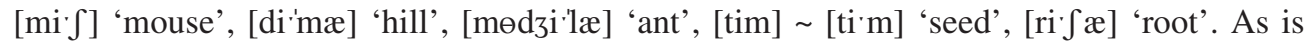
evident in these examples, historical $*_{\overline{1}}$ and $* \overline{\mathrm{u}}$ have merged into /i/; for example, $m i \check{s}<$ mūš 'mouse', riša < rī̌sa 'root'.

2.2.4. /e/ is half long and is principally derived from Middle West Iranian *ē, as in jer

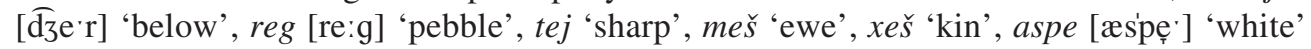
(<Mid. West Ir. *spēd), ke 'who' (cf. New Pers. kū , Mid. Pers. kē). Note the minimal pair between /e/ and /i/, in der 'late' ( $<$ dēr $<*$ dayr $<*$ dagr) versus dir 'far' $(<$ dūr); cf. Pers. dir and dur respectively. Note also šir [ $\left.\int \mathrm{i} \cdot \mathrm{r}\right]$ 'lion' ( $<$ šêr $<*$ šayr $<*$ šagr), which has become homonymous with šir 'milk' (< šīr); therefore, both words are likely borrowings from Persian.

There are a few cases in which /e/ has other origins: per [per] [perr] 'father' (probably, as other varieties of Caspian imply, with the protoform *pıər, from Mid. West Ir. *pidar), še $\breve{s}$ [ e $\left.\int\right]$ 'six', and the "inverse-eżäfa" marker (\$3.2), which is used to form possessive pronouns (me, te, e, etc.; Table 2).

There are instances where [e] overlaps with [I], as in aspez [as'pez] $~$ [æs'pız] $~[$ [s'pez] 'louse' (< OIr. *spiš-).

2.2.5. / $/$ /. The space between the phonemes /e/ and /a/ is filled with a range of open-mid vowels that includes $[\varepsilon$, ə, 3]. These sounds at times overlap with /a/, less likely with /e/, and therefore could reasonably be placed in the domain of either of these principal neighboring phonemes. On the other hand, the high frequency of the range $\left[\begin{array}{lll}\varepsilon & \partial\end{array}\right]$ affords a distinct phoneme, designated in this study as $/ \varepsilon /$, which by and large agrees with the symbol $ə$ used by Dabir-Moqaddam. I could not identify any minimal pairs in the data between either $/ \varepsilon /$ and $/ \mathrm{e} /$ or $/ \varepsilon /$ and $/ \mathrm{a} /$. However, in support of a phonemic status for $/ \varepsilon /$ it should be added that, notwithstanding its frequent allophonic intersection with /a/, the Šahmirzādi speakers commonly perceive it as Persian kasra far more than fatha. The following examples from the

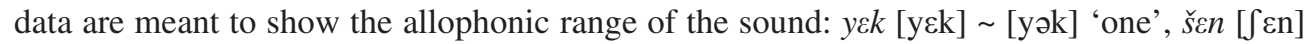

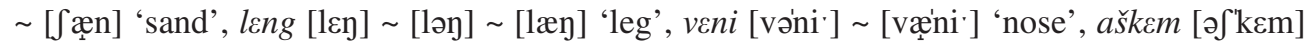

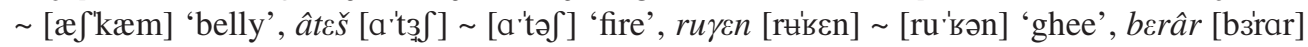

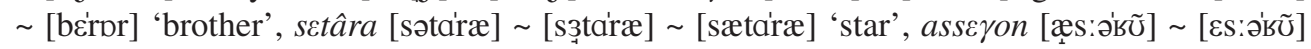
'bone', $\operatorname{\varepsilon sm}[3 \underset{s}{ } \mathrm{~s}(\mathrm{~m})] \sim[$ [æs $(\mathrm{m})]$ 'name'.

2.2.6. In final position a front-mid vowel is heard in the following words of obscure etymon: zâye 'grandchild' (<? zādak), xale [xælẹ'] 'many' (cf. Tajik xale), lave [læ'vẹ] 'pot', $s \hat{z} z \varepsilon$ [sa'ze] 'broom'. Nevertheless, the most common outcome of Middle West Iranian *-ak

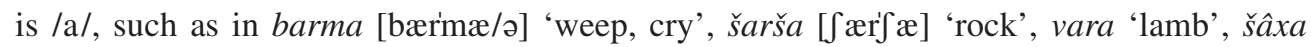
'branch', and the unstressed third person ending (Table 5). More work is needed to determine if word-final $/ \mathrm{a} /$ and $/ \varepsilon /$ really contrast or the variance is caused by a wavering pronunciation of one underlying form.

2.2.7. /a/ covers a wide range in the front open quarter of the vowel space, that is, open [a], near-open [æ], and central-unrounded [r], as well as less open articulations in the speech of some speakers. It is therefore not always clear how to distinguish this phoneme from its neighbor $/ \varepsilon /$ (see §2.2.5), as in [dæl] [d șl] [del] 'heart' and [k3rk] [kerk] 'hen'. Apart from the strong tendency to centralize, both allophones [æ] and [a] can be heard in the speech of the same speaker in the data: [sæk $\mathrm{k}^{\mathrm{h}}$ ' dog', [næet] 'dirty' vs. [gal] 'throat', [das] 'hand', [mard] 'man'.

2.2.8. Round back vowels are /o/ and /u/ and their front rounded allophones /ö/ and /ü/, which appear to have higher frequencies than their back counterparts. Historical centralization or fronting of back rounded vowels, atypical of the Caspian languages (cf. §2.2.11), is in 
all likelihood a local development of Šahmirzādi, and if so, the historical process of fronting is not yet complete. On the other hand, one may reasonably assume a regression from central $\ddot{o}$ and $\ddot{u}$ toward o and $\mathrm{u}$ under the more recent influence of Persian, considering the rarity of $\ddot{o}$ and $\ddot{u}$ in the speech of younger speakers.

In this study I have elected the fronted pair as principal phonemes, on the grounds of higher frequency of ö and $\ddot{u}$ and their rarity in the speech of younger speakers. Erik Anonby (pers. comm.) views o and $\mathrm{u}$ as the underlying phonemes, for reasons of descriptive symmetry in the structure of the vowel system and the fact that the typologically more common vowels o and $\mathrm{u}$ are more likely to have fronted allophones, than front rounded vowels ö and ü are to have backed allophones.

2.2.9. /o/ is commonly close-mid central $[\Theta]$ and can be realized as $[\mathrm{o}, \mathrm{v}]$ as well.

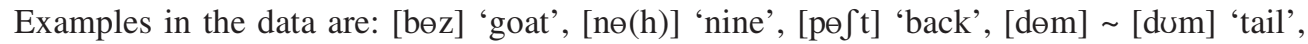

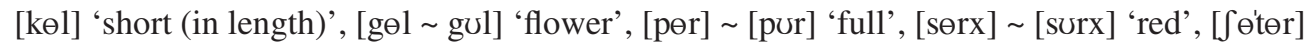
[S'oter] 'camel', [be'mordæ] 'he died', [bө'xotæ] 'he slept', [bө'gọtæ] 'he said; he grasped', [bəpөr'siæ] [bepor'siæ] 'he asked'.

As the examples above reveal, /ö/ is generally derived from historical short *u. Additionally, the sound may have developed via a transitional *u (see $\$ 2.2 .10)$, as in [de] [d $\left.{ }^{\prime}\right]$ 'two' (<*dō), [te] [to] 'you' (<*tō), [kưte] [küta'] 'child' (cf. Pers. kōdak), [mөdzi 'læ] 'ant' (probably cognate with Pers. mōr-ča, with metathesis), [me] [me] $\sim[\mathrm{mu}]$ 'I' (<*mun $<*$ man). There are also words that do not follow such derivation: sö [se] 'three' $(<* \mathrm{se}),{ }^{5}$ [bijơrda] 'he brought' ( $<* \bar{a} r-<* \bar{a} w a r-)$, and these words of obscure etymon: [qe' $\int \mathrm{a}$ 'r] 'pressure', [ko'lef] 'cough'. 6

2.2.10. / $\ddot{\mathrm{u}} /$ stands for the allophones $[\mathrm{u}]$ and $[\mathrm{u}]$, of which the latter is usually heard somewhat longer. Morgenstierne's (1960: 94) hypothesis that this Šahmirzādi vowel ( $\overline{\mathrm{u}}$ in his transcription) is a development of the old majhul vowel ${ }^{7} \overline{\mathrm{o}}$ is supported by my data: $\ddot{u}$

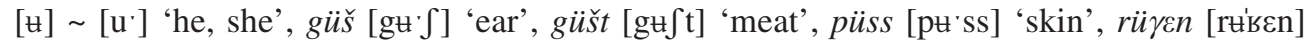
[ru'вәn] 'ghee', süt- 'burn' (in [bæ'sut'æ] 'it burned'), etc. There are however numerous words in which /ü/ stems from the ma'ruf vowel ū, e.g., bâzü [ba'zu] 'arm' (< bāzūk), zânü [zD'nu] 'knee' (<zānūk), sülâx 'hole' (< sūrāx), ma:lüm 'apparent' (< ma'lūm). Moreover, the multiple sources of /ü/ are evident from süzi 'grass' (< sabz), [gu'] 'cow' (<*gāw ), [zu'n] 'tongue' (cf. Mid. Pers. uzwān, Parth. izßān), among other words. All these sound changes suggest a merger of $\overline{\mathrm{o}}$ and $\overline{\mathrm{u}}$, first into $\breve{\mathrm{u}}$, then fronted but with an uncompleted outcome (see §2.2.8). Note also [ku’l] 'bark of trees' (also in Mazandarani) and lülü/lü̈li (Žuk. lölii) 'dress, clothes', whose etymons are unknown to me.

2.2.10.1. Near-close near-front rounded vowel $[\mathrm{Y}]$ may be considered another allophone of /ü/, as it is heard in süzi [sy'zi'] [st'zi'] 'grass', sülâx [sy'lax] [st'lax] 'hole', nü [ny] $\sim[\mathrm{nu}]$ 'new'. Note also $n \ddot{o}(h)[\mathrm{n} \varnothing \mathrm{h}] \sim[\mathrm{nyh}]$ 'nine'.

2.2.11. Diachrony. Chart 1 exhibits a general hypothesis for vowel diachrony in Šahmirzādi. The upper row is the hypothetical vowel inventory of Middle West Iranian, inferred from Middle Persian and Parthian, the only two known West Iranian languages of the period. ${ }^{8}$ Middle West Iranian is taken here as a historical frame of reference in the absence of any known ancestor to the Caspian language group. Only major developments are shown;

5. The vowel in 'three' can be ascribed to analogy when counting (do, so . . ; dö, sö . .). This sound change is parallel to h arising on hašt 'eight' by analogy with haft 'seven' (pers. comm. Erik Anonby).

6. See also $\$ 2.2 .10 .1$.

7. On majhul and ma'ruf vowels, see Perry 1996.

8. See Skjærvø 2009: 200. 
so, details such as $* \bar{a} \mathrm{~N}>\mathrm{uN}$, as in juma 'shirt', are ignored for simplicity. Accordingly, Šahmirzādi differs from Persian essentially in keeping the front majhul $* \bar{e}$ and in fronting of round back vowels. Noteworthy is the double step in the fronting of $* \overline{\mathrm{u}}$, that is, halfway to / ̈̈/ in some words (\$2.2.10) and fully to /i/ in others (\$2.2.3). In this respect, the distribution of Šahmirzādi words carrying /ü/ and /i/ from *ū accords well with those of Mazandarani proper, for which outcomes are /u/ and /i/; this can be seen in Šahm. gǚ̌ and di versus Maz. guš and did for 'ear' and 'smoke'.

Middle West Iranian

Šahmirzādi

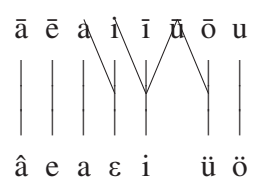

ü $\ddot{0}$

Chart 1. Vowel Diachrony

2.3. Stress. The stress is word final in nouns, with just a few exceptions following the norm in Persian, in adverbs such as xále 'very'. Verb forms appear to follow the stress patterns of Mazandarani proper (see Borjian 2005): the stress is on the verbal prefix in the imperative (báxor 'eat!') and the subjunctive (báxori 'that you eat'); penultimate in the present-future (xorémma 'I eat'); on the final syllable of the past stem (ba-rekki-a 'he scratched', da-pất-a 'he threw'); and on the nominal component (vấ dakita [lit. wind (n.) it-fell] 'it swelled', sâzé bezia 'he swept'). The negation marker (\$4.7) always takes the primary stress.

\section{NOUN PHRASE}

3.1. Number. The common plural marker is $-(h) \hat{a}$, as in siuhâa 'apples' and $\operatorname{karg}(h) \hat{a}$ 'hens', while -ón is attested in zanon 'women'. In Purkarim's data only, the plural marker is predominantly -un, e.g., miun 'hairs', čašun 'eyes', dârun 'trees'.

It should be noted however that plurality is seldom specified overtly in Šahmirzādi, as is the case in the Mazandarani variety of Dodānga. Singular forms are habitually used for the plural especially when the context takes care of quantity. A case in point is illustrated in the following Šahmirzādi sentence, followed by the Persian one it was evoked from:

\begin{tabular}{llll} 
Šahm. & $\begin{array}{l}\text { angir- } \emptyset \\
\text { grape-SG }\end{array}$ & hama & \multicolumn{2}{l}{$\begin{array}{l}\text { širin=ena } \\
\text { sweet=COP.3PL }\end{array}$} \\
Pers. & $\begin{array}{l}\text { angur-hâ } \\
\text { grape-PL }\end{array}$ & $\begin{array}{l}\text { širin } \quad \text { ast } \\
\text { sweet } \quad \text { COP.3SG }\end{array}$
\end{tabular}

"The grapes are sweet."

Noteworthy in the above sentence is the association between the verb and the subject in terms of number, contrasting with the Persian model, where the third singular copula serves the plural inanimate subject. Nevertheless, Šahmirzādi allows Persian style copulative sentences:

$$
\begin{array}{lll}
\text { in } & k u \check{s}-\hat{a} & m e ́=a \\
\text { this } & \text { shoe-PL } & \text { my=COP.3SG }
\end{array}
$$

"These shoes are mine."

3.2. Modifiers. Adjectives and noun modifiers precede the head noun, separated by the marker $-e$ (with free variant $-\partial$ ). This noun-phrase binder is designated by Donald Stilo 
Table 2. Personal Pronouns

\begin{tabular}{|c|c|c|c|}
\hline & Subject & Object & Possessive \\
\hline Sg. 1 & $m \ddot{~}$ & már $(a)$ & me \\
\hline 2 & $t \ddot{o}$ & tár(a) & te \\
\hline 3 & $\ddot{u}$ & $\ddot{u r}(a)$ & $e$ \\
\hline Pl. 1 & (h)amá́ & (h)amấra & áme, hámi \\
\hline 2 & šamá & šamấra & šáme, šámi \\
\hline 3 & un(h)ấ, öšön & unấra, öšónra & öšön(e) \\
\hline
\end{tabular}

(2001) as "inverse-eżāfa," on the grounds that the noun phrase structures in Caspian and Persian are the inverse of each other. Examples: possessives: böz-e sar "goat's head," bözâye sar "goats" heads"; adjectives: sörx-e göl "red flower," sörx-e gölâ "red flowers." For objects of postpositions, see $\$ 3.4$.

3.3. Pronouns. Personal pronouns are declined in the ternary system typical of Caspian languages (Stilo 2001), that is, subject, object, and possessive cases. Table 2 demonstrates the most typical of the forms documented. ${ }^{9}$ It is worth mentioning that, following the Caspian pattern, there are no pronominal clitics in Šahmirzādi.

The object set is formed by suffixing the object marker $-r a(\$ 3.5)$ to the subject set; the vowel sound of the object marker is liable to elision, while $-r$ is always present. Example:

$$
\begin{array}{llll}
m \ddot{o} & \ddot{u r a} & \text { tar } & \text { demma } \\
\text { 1SG.SBJ } & \text { 3SG.OBJ } & \text { 2SG.OBJ } & \text { I.gave }
\end{array}
$$

"I will give it to you."

The possessive set me, te, $e$, etc., ${ }^{10}$ precedes the head noun when used as adjective (e.g., me detar "my daughter," e esm "his name") and precedes the copular verb when used as pronoun, as in in kušâ mé-a "these shoes are (lit. is) mine," in ti-a? "is this yours?"; cf. the interrogative in kušâ káni-a? "whose shoes are these?"

3.3.1. Demonstrative pronouns are proximate in (object ine/inna, plural inhâ) and distal un (object une/unna, plural unâ). Demonstrative adjectives have no plural.

3.3.2. The reflexive is impersonal xošten ${ }^{11}$ with the variant $x o s ̌$ in the third person singular. These words may function as (1) reflexive pronouns: xošténn-a makelâšte "he scratched himself," Dabir. mö xöšten- $\propto$ ayne-dcela ba-di-ma (I self-OBJ mirror-in PFV-see.PST-1SG) "I saw myself in the mirror"; (2) possessives: Žuk. xū̌s zanrō bogóta "he told his wife," Pur. mö ü-rce hagetєmae xošten-e düs-jen "I took it from my friend"; Kalb. xoš duš-e dim vešta "he put it on his shoulder," Kalb. xoštan-e fekr-e dele "in his thoughts."

3.3.3. Relative and interrogative pronouns and adverbs are ke/ki 'who', köjalköjâ 'where', čači/čeči 'what', čokâ 'why', čati 'how', čan 'how many'. Demonstrative adverbs are inja 'here' and unja 'there' (see also §3.3.1).

9. For variation in sources, see Rastorgueva and Edel'man 1982: 509.

10. The possessive forms are likely to have emerged from the collision of the subject forms and the marker $-e$ (Borjian 2005), for which see $\$ 3.2$.

11. See $\$ 5.5$. 
3.4. Adpositions. Postpositions are the norm in Šahmirzādi ${ }^{12}$ as in other Caspian varieties. ${ }^{13}$ Common postpositions are v(e)ra, ev 'for', dela, danim 'in', jen 'from', hamrâ, bâ '(along) with' (comitative), vari, bâ 'with, by' (instrumental), dim, sar 'on', jer, beni 'under', vâri 'like'. This inventory of postpositions is in general agreement with that of Mazandarani proper, save for bâ, which is rare in Mazandarani. Also uncommon is danim (<? dar-miān). Note also the single occurrence vista in Chris. joek kotáki-vistä "about a child." Objects of postpositions normally receive the marker -e (cf. §3.2) when they are not vowel-final. Examples:

Kalb. zan me-vra kota urana "the wife will bring me children"

Dabir. katab-ev jaeld baxar "buy a cover for the book"

Pur. vaerf aftab-e dela $\bar{u}$ bünce "snow melts in the sun"

Dabir. mö xöšten-ce ayne-daela baedima "I saw myself in the mirror"

Kalb. mö masjed-e danim davema "I was in the mosque"

Kalb. e das goma jan belarziya "the jar slipped off his hand" 14

Pur. köje jen ani "where are you coming from?"

Pur. $\ddot{u}$ ben(n)eke jen jēr ketce "he has fallen down off the roof"

Dabir. me-jan bolantoer "taller than me"

Kalb. me hamrâ "along with me"

Pur. e-ba čekar hakuni? "what will you do with it?"

Chris. bäqqál übå šüxí håkárda "the grocer joked with him"

Dabir. u dar-rae kali-vari va hakardae "he opened the door with the key"

Dabir. mö divar-e-dim tekye hadama "I leaned against the wall"

Kalb. zamin-e dim "on the ground"

Pur. ta-rae masüre-i dim depitzn "to spin yarn on (around) a spindle"

zamin-e sar "on the floor"

Kalb. karg-e jer "under the hen"

Pur. mö benišstema yek dare bun "I sat under a tree"

Chris. te sár me sàre vorí kal bävéa "your head is bald like my head"

Pur. sölp-e vari scygin-e "it is as heavy as lead"

3.5. The object marker for the accusative and dative is likely to be derived from the Persian morpheme $-r \bar{a}{ }^{15}$ in the forms $-r a,-a,-r .{ }^{16}$ Examples of usage:

un miš-ra hišin "look at that mouse!"

Kalb. mard-a bogota "he told the man"

Dabir. ama-r xavar dannce "they will let us know"

Pur. mar xu giren(n)a (lit. for me the sleep grasps) "I am (becoming) sleepy" mar sard-a (for Pers. sard-am ast) "I am cold"

12. Notwithstanding the preponderance of prepositions in Christensen's list (1935: 170-71), e.g., äz ság tarsámmam "I fear dogs."

13. See, i.a., Yoshie 1996: 22 for the Mazandarani dialect of Sāri; Stilo 2001 for Gilaki.

14. Note that jan should logically follow e das.

15. For the emergence of -rā in Persian, see Lazard 1970.

16. See also $\S 3.3$ and Table 2 . 


\section{VERB PHRASE}

4.1. Verb stems. Many Šahmirzādi past stems show irregular synchronic accord with their present pairs; examples are (present stem : past stem) vin- : di- 'see', $\hat{a}-:$ ame- 'come', ${ }^{17}$ ruš: rut- 'sell', el- : ešt- 'put, allow'. Regular past stems are synchronically derivable by adding a past formant to the present stem, as in vâf- : vâf-t- 'weave', xor- : xor-d- 'eat', kan- : kan-i'dig', mun- : mun-ess- 'stay'.

4.1.1. Among the aforementioned past stem formants, $-i-\left(<^{*}-\overline{1} d-\right)$ is productive in the causative construction: causative present and past stems are formed by adding to the intransitive present stem the causative morphemes - $\varepsilon n$ - ( $<*$-ānd-) and -Enni- $(<*$-ānd-īd-) respectively, as in xos- : xot- 'sleep' vs. xosen- : xosenni- 'put to bed'; xor- : xord- 'eat' vs. xoren- : xorsnni- 'feed'.

4.2. Preverbs. Lexicalized preverbs are $(h) \hat{a}-$, da-, ve-. They occur in ha-kon- : -kard'do', hâ-gir- : -gat- 'seize'; da-van- : -vass- 'close; get firm', da-pič- : -pit- 'twist, fold', dakon- : -kard- 'spill, shed; dress', da-pač- : -patenni ${ }^{18}$ 'throw'; ve-gir- : -gat- 'pick up', v-el- :

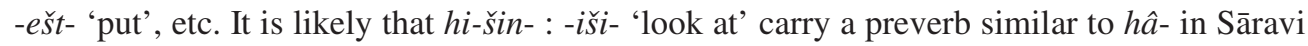
Mazandarani present stem $h \bar{a}-r-e \check{-}$ - 'id.' (with epenthetic -r-). Note also de-pât- 'pour' vs. vapât- 'winnow', which may correspond to Lasg. bepoton 'scatter', Maz. of Espivard he-pâj- : -pât- 'sift (the threshed harvest)'. Žukovskij documented de-pož- : -pot- for Pers. rixtan, Russian prolivat'sja 'fill, pour'; its present stem might be either pâj- or pâš- (on account of absence of /ž/ in Šahmirzādi), the latter of which is comparable with Pers. pāš- 'scatter' (<Iranian root *parš; Cheung 2007: 298; Hasandust 2010: 611).

4.2.1. Preverbs preclude the modal-aspectual prefix $b a$ - (\$4.3). They normally accompany the stem in all tenses, including the present indicative, e.g., hâkúmma "I do" (cf. Sāravi kəmbə 'id.'), a feature that separates Šahmirzādi from Mazandarani proper. See more in $\S 4.3 .1$.

4.3. Modal and aspectual affixes. The modal-aspectual prefix $b a$ - (with varying vowel) marks the imperative, subjunctive present, preterite, past participle, and infinitive. The imperfective aspect is asymmetric in the present and the past, as discussed in the following sections.

4.3.1. The durative past is marked by $m a$ - (with varying vowel), prefixed to the stem (or to the negative maker; see $\$ 4.7$ below): mo-got-a "he used to say, he would say," hâ-ma-kard-a "he used to do," Žuk. de-mī-pút-uma "I would turn," Chris. har váqt ke bäqắl xunä mäšéa, un tü̈tí däkún-rä mäpå̀s $\ddot{a}^{19}$ "whenever the grocer went home, the parrot would look after the store." This past imperfective marker, apparently originating in Persian ${ }^{20}$ and passed on to the Semnān area, marks a significant isogloss between Šahmirzādi and Mazandarani. ${ }^{21}$

4.3.2. The present indicative employs a nasal morpheme, $-(V) n-$ or $-(V) m-$, wedged

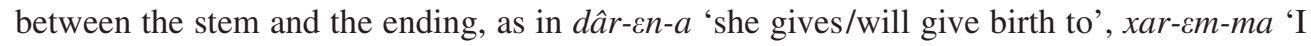
(will) buy', de-m-ma 'I (will) give'. Should this infix be a remnant of Old Iranian present

17. These two stems are historically suppletive.

18. The past stem is causative in form: pat-Enni-. See §4.1.1. Synonymous verbs for 'to throw' are döm badâzn and jer-Engian.

19. The conjugations in this sentence are ambiguous. The second verb has the stem pâs-, corresponding to Pers. pādan, pāyidan 'to guard'.

20. See Lazard 1963: 297.

21. The imperfective prefix me- is used for both the present and the imperfect in the Perso-Tabaric dialects that surround Mazandaran. See Borjian 2013b, §3.5.1. 
Table 3. Verb Endings

\begin{tabular}{rll}
\hline \hline & Indicative & Subjunctive \\
\hline Sg. 1 & $-m a$ & $-(a) m$ \\
2 & $-i$ & $-i$ \\
3 & $-a$ & $-a$ \\
Pl. 1 & $-m i$ & $-i m$ \\
2 & $-n i$ & $-i n$ \\
3 & $-n a$ & $-a n$ \\
\hline
\end{tabular}

participle marker *-ant- ${ }^{22}$ the original $n$ sound of the morpheme has been assimilated to the $m$ sound of the first person ending (Table 3). From a synchronic vantage point, this morpheme may be taken as a part of present-tense personal endings, to form the distinctive set

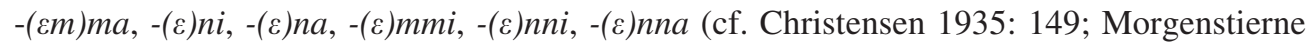
1960: 108; Borjian 2005). Alternatively, Dabir-Moqaddam (2014: 1045) regards the infix as an integral part of the present stems, e.g., šün-/š̈̈m- 'go'. See also §4.4.1.

4.4. Person markers. Verb personal endings, shown in Table 3, are of two types: (1) the indicative set applicable to the present, the preterite, and the imperfect, and (2) the subjunctive set specific to the subjunctive present. ${ }^{23}$ An epenthetic vowel ( $\varepsilon$ or $\partial$ or $a$ ) may stand between the stem and ending. Christensen (1935: 149) has an alternative, fuller set of indicative endings (first person singular -mam, etc.), apparently a result of mingling with Persian verb endings.

4.4.1. In the present indicative, the first person singular ending may contract or drop entirely, as in xor-Ém-ma $\rightarrow$ xoréma, xorém 'I eat'; yet, the outcome stays distinct from any other person or tense. Likewise, the first person plural forms optionally conjugate without nasal germination, as in xor-Ém-mi $\rightarrow$ xorémi 'we eat'. Moreover, stems ending in $/ \mathrm{n} /$ lose it in the second and third person conjugations to avoid gemination of the nasal in the singular, hence keeping the singular and plural distinct; for instance, present stem zen- 'hit' yields third singular $z e-n-a$ versus third plural $z e-n-n a$. Stems ending in /r/ normally lose or assimilate it depending on the person marker, as does the stem $d \hat{a} r-$, yielding $d \hat{a}-n-a$ 'he has', dâ-n-na 'they have', dâ-m(-ma) 'I have'. However, this rule does not hold under the condition that a merger with another verb would be possible; for instance, by resisting contraction $\check{s} u r-\varepsilon m-m i$ 'we wash' stands distinct from $\check{s} u-m-m i$ 'we go', as does $x o r-\varepsilon n-n a$ 'they eat' from xon-En-na 'they read'. ${ }^{24}$ See also §4.5.

4.4.2. The imperative takes no ending for the singular: be-ruš 'sell!' bi-rij 'flee!' ba-paj

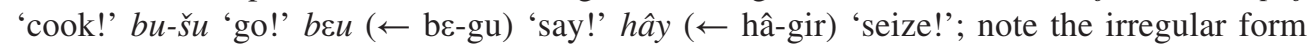
buru 'come!' (with suppletive stems $\hat{a}^{-}$: ame-). The plural imperative takes the ending -in.

4.5. Tense, aspect, mood. Simple verb forms consist of the imperative, present indicative and subjunctive, preterite (simple past), and imperfect (Table 4). There is no present perfect in Šahmirzādi; preterite is used in its place.

The two inflective past forms share the stem (past) (\$4.1) and the ending (indicative) (Table 3); the distinction between the simple and continuous past is made by aspect markers (§4.3): perfective $b a$ - and imperfective $m a$-. See Table 4 for paradigms.

22. See Azami and Windfuhr 1972, p. 198.

23. See also Table 6 for copulas.

24. Cf. Žuk., Chris. xun-en-na. 
Table 4. Conjugation of "eat"

\begin{tabular}{|c|c|c|c|c|}
\hline & \multicolumn{2}{|c|}{ Present } & \multicolumn{2}{|c|}{ Past } \\
\hline & Indicative & Subjunctive & Simple & Continuous \\
\hline Sg. 1 & xor-Ém-ma & bá-xor-am & bo-xórd-\&ma & 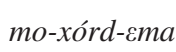 \\
\hline 2 & xor-en-i & ba-xor- $i$ & bo-xord-i & mo-xord-i \\
\hline 3 & $x o r-\varepsilon n-a$ & $b a-x o r-a$ & bo-xord-a & mo-xord-a \\
\hline Pl. 1 & xor-em-mi & ba-xor-im & bo-xord-\&mi & mo-xord-zmi \\
\hline 2 & xor-En-ni & ba-xor-in & bo-xord-\&ni & mo-xord-вni \\
\hline 3 & xor-en-na & ba-xor-an & 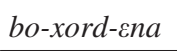 & mo-xord-вna \\
\hline
\end{tabular}

Table 5. Verb Forms

(for the 3rd person singular)

\begin{tabular}{ll}
\hline \hline Present & xoŕ́na \\
Subjunctive & baxora \\
Imperative (2 sg.) & báxor! \\
Preterite & boxórda \\
Imperfect & moxórda \\
Pres. progressive & dar $($ a) xorsna \\
Past progressive & dave moxorda \\
Pluperfect & boxórd be \\
Perfect subjunctive & boxórd bö \\
\hline
\end{tabular}

The present-tense forms are divided by the mood. The indicative covers habitual as well as future. It is formally distinguished from the subjunctive by two morphemes: the ending set (Table 3) and the mood-aspect markers ( $\$ 4.3)$, that is, the subjunctive prefix $b a$ - and the durative infix -en-. This redundancy permits a considerable degree of leniency in the conjugation of the present indicative tense, as explained under Person markers above (\$4.4.1). See Table 5.

4.6. Periphrastic forms. These include two perfective and two progressive tenses which are constructed analytically with substantive and locative verbs (\$4.8) as auxiliary.

4.6.1. The pluperfect and the perfect subjunctive employ the past participle (\$4.10.1) with the past and subjunctive of 'be' (Table 6) respectively, as in bevörd bena "they had taken away," vagét bâm" "I may have picked up," mö ke baresima ü bašé be "he had gone when I arrived," age ü bašé bö ma:lüm büne "should he be gone, it will be known."

4.6.2. The progressives receive the imperfective conjugation preceded by the present or past of the locative verb $(\$ 4.8)$; the present locative optionally remains unconjugated. Examples: Pur. jü dar res(s)ene "the barley is ripening," Dabir. dar(-enæe) nasihat ha-ku-nnce "they are giving advice," dcev-ence ncesihat ha-me-kard-ence "they were giving advice," Kalb. davema kota-ra mogotam ${ }^{a}$ "I was telling the child."

4.7. Negation. The negative marker ná-precludes the modal prefix $b a$ - and the preverb $h \hat{a}-$ and succeeds that imperfect marker ma-. Examples: güš me-né-kerd-a "he wouldn't listen," Žuk. me-ná-xōrd-ī "you wouldn't eat," Chris. jävắb mänádå "he wouldn't answer" (p. 174). Prohibition is marked by either na- or ma-, as in nákon "don't do!" mékelâšta "don't scratch [yourself]!" The second form is apparently older, corresponding to classical Persian ma-. 
Table 6. Copulas

\begin{tabular}{rlll}
\hline \hline & Present & Subjunctive & Past \\
\hline Sg. 1 & $-e m(a)$ & bâm & béma \\
2 & $-i$ & bi & bi \\
3 & $-e /-a$ & bö/bü & be $(a) / b i a$ \\
P1. 1 -em $(i)$ & bem/bim & bemi \\
2 & $-e n(i)$ & ben/bin & beni \\
3 & $-e n(a)$ & ben/ban & bena \\
\hline
\end{tabular}

4.8. Copulative and locative verbs. 'Be' is expressed by two verbs: copulas and locativeexistential. The present copula equals the indicative set of person markers (Table 3), optionally on the base $(h) a s(s)$-. The subjunctive and the past are built on the stem $b(e)$ - (Table 6). The locative-existential verb is formed with the stems dar- (present) and dav-(past). These two verbs function as auxiliary in periphrastic verb forms (\$4.6).

Examples: Copula: šu târik-a "night is dark," mo Ali-e zumâ hass-em(a) "I am the son-inlaw of Ali," Morgen. ü mahin-ase "he is big," (past) Chris. širin-zäbún béa "he was sweettongued," (subjunctive) har jâ dara, tandoros bü "wherever he is, may he be in good health." Locative: me inja dár-ema "I am here," Pur. pirezän yeke därä "the old woman lives alone," kojâ dav-i? "where were you?" Kalb. e dele mâst davaa "there was yogurt in it," hamin yag $\check{s}$ u-ra inja daven "be ye here this very night," dumma har-jâ davü (Pers. bāšad), tandoros hassa "I know that wherever he may be, he is in good health."

4.8.1. 'Become' is conjugated regularly on the present stem bü- (medially, -vü-) and the past stem $v$-. 'Be' and 'become' merge in the subjunctive. Examples: xub büma/navüma "I will become/not become well," be ommid-e xodâ xub bünni "by God's grace you (pl.) will get well," nâxoš bavéma "I became sick," battar me-v-e "he used to get worse," Kalb. maryona čitikâ büna . . e e čitikâhâ mahin bünna "the egg becomes chick . . . her chicks will grow big." Counterfactual: Pur. age $\bar{u}$ baba müxardemce "if there were water, I would have drunk [it]." More data are needed to arrive at a full paradigm for 'become'.

4.9. Modal verbs. The impersonal modals vân(ə) (pres.) and vâs(ə) (past) convey both meanings of 'must/should' and 'want'. They are succeeded by the present subjunctive of the main verb, as in vân/vâs baxori "you should eat/you should have eaten," Žuk. vốna gusl hōkunî́m "we must perform ablutions," Žuk. vôssa ur azób hókunam "I must castigate him," in böz-ra vân davassan "this goat must be tied" (with the infinitive); Dabir. un mardi van $b \bar{e}$ "that man wants to come," Žuk. tüflo (tüfl?) mer névōna (for Pers. tefl-rā nemix $x^{w} \bar{a} h a m$ ) "I don't want the child" (lit. for me the child is not a must), Pur. $\bar{u}$ navvance daevi "he doesn't want to stay (lit. to be in)," Pur. aegaer taer vānae e-ba čekar hakuni? "if you want it (lit. if it is desired by you), what will you do with it?" Pur. vas(s)a börim baše "he wanted to go out."

'Want' may alternatively be expressed by the verb xâstan, e.g., Chris. ín kotákrā náxåmmam "I don't want this child" (p. 174), Žuk. ensốf bexốstena "they requested judgment."

4.10. Verbal nouns. The infinitive is formed on the past stem $(\S 4.1)$, prefixed by $b V$ - or a preverb (\$4.2) and suffixed by -(a)n, as in bo-xord-an 'to eat', hâ-kard-an 'to do', ha-dâ-n 'to give', $b a-z \partial-n$ 'to hit', bö-pörsi-n 'to ask'.

4.10.1. The past participle is formed of the past stem and prefix $b V$-. It normally appears without a suffix when employed in perfect tenses (Table 5 and $\$ 4.6 .1$ ), but is suffixed by -e/-a when used as a participial adjective: Žuk. besüté nun "burned bread," Chris. bäpetá "cooked," Pur. zang-beze(y)a "rusted". The vowel - $e /-a$ is normally elided when the stem 
Table 7. Divergent Cognates

\begin{tabular}{|c|c|c|c|}
\hline Gloss & Šahmirzādi & Semnāni & Old Iranian stem \\
\hline big & mahin & masin & *masya- \\
\hline son & pesar & pir & 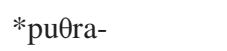 \\
\hline three & $s \ddot{~}$ & he(y)ra & $*$ rraya- \\
\hline $\operatorname{dog}$ & sak & esba & *spa-ka- \\
\hline yesterday & adi & $i z i$ & $*_{\text {zya-ka- }}$ \\
\hline door & dar & bar & *dwar- \\
\hline woman & $z a n$ & jini & $*_{\text {jani- }}$ \\
\hline
\end{tabular}

ends in a vowel, e.g., Pur. jü beresi $i_{1}-a_{2}$ "the barley is ${ }_{2}$ ripe(ned)." The boundary between the categories of periphrastic verb and copular clause tend to be untidy for the stems ending in vowels; for instance, the sentence $e$ dim juš baze bea "his face was pimpled" (with the stems zan- : zə- 'hit, stricken') may contain either the compound adjective juš-bazé or the pluperfect júš baze bea, depending on the position of the stress.

4.10.2. The present participle can be the present stem only, usually suffixed to a noun, as in kâr-ten 'weaver', aškem-dâr (lit. having a belly) 'pregnant', sarmâ-gir (Pers. sarmâ'i; cf. French frileux) 'sensitive to the cold; one who is always cold'. Alternatively, the present participle may take the suffix -ana (<-anda), as in gazana-mâz 'biting wasp', tarssna (for Pers. tarsu) 'one who fears habitually, coward, sheepish'. Note also angir-bačin, for Pers. angur-čini 'grape harvesting'.

\section{LEXIS}

The lexical inventory of Šahmirzādi is in close agreement with that of Mazandarani proper, but not without a certain degree of convergence towards its neighbors in the Semnān area, ${ }^{25}$ as well as its own idiosyncrasies.

5.1. Caspian pedigree. As a Caspian variety, Šahmirzādi is genetically distinct from all its neighbors, including Semnāni, Sorxa'i, Lāsgerdi, Aftari, and Sangesari. As such, cognate words may differ considerably among these languages. Table 7 illustrates Šahmirzādi and Semnāni words that share an etymon but diverge in form beyond recognition for an average speaker. Other languages of the region generally follow Semnāni in phonological development, while Sangesari shows deviation, as, for example, in the outcome $\breve{s} e$ for the isogloss 'three'.

5.2. Mazandarani inventory. In order to arrive at an estimation of the lexical agreement between Šahmirzādi and Mazandarani proper, I used a list of basic vocabulary collected by Kolbitsch (2008). It is a Swadesh-type list of 227 items based on the modified list prepared by Anonby (2003) for the languages of Iran. Of the 227 Šahmirzādi items of the list, only 33 items (15 percent) show significant disagreement with Mazandarani proper. These are listed in Table 8. We may further break down the latter into the words with major phonological deviation and the words of different roots. The latter reckon 18 in the table, constituting 8 percent of the list. 
Table 8. Šahmirzādi vs. Mazandarani Wordlist

\begin{tabular}{|c|c|c|c|}
\hline Gloss & Šahmirzādi & Mazandarani & Notes \\
\hline tongue & $z u n$ & zəvun & syncopated \\
\hline throat & gali & gal & 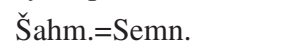 \\
\hline finger & angöšt & angus & Šahm.=Semn. \\
\hline knee & karb, zânü & zânu & \\
\hline bone & asscyon & essekâ & Šahm. $=$ Semn. \\
\hline $\operatorname{man}$ & mard & mardi & \\
\hline woman & $z a n$ & $z ə n a ̂$ & See Tab. 7 \\
\hline child & $\operatorname{kota}(k)$ & vačə & See $\S 5.5$ \\
\hline chick & čitekâ & čindekâ & See $\$ 5.5$ \\
\hline snake & döm-darâz & mar & See $\$ 5.6$ \\
\hline ant & möjila & məlija & metathesis \\
\hline spider & haštpâ & $\operatorname{ban}(d)$ & \\
\hline leaf & valg & gelâm, valg & \\
\hline cloud & $a b r$ & miâ & Šahm.=Semn.=Pers. \\
\hline hill & tappa, dima & tappə, din & \\
\hline dew & hasâr & šebra & \\
\hline river & čâka & $\check{c ̌ u k \partial}$ & See $\$ 5.3$ \\
\hline house & xuna & sare & persianism \\
\hline oil, ghee & ruүen & 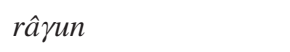 & \\
\hline one & $y \varepsilon k(k a)$ & atta & persianism \\
\hline three & $s \ddot{0}$ & se & See $\$ 2.2 .9$ and Tab. 7 \\
\hline good & $x u b$ & $x a ̂ r$ & persianism \\
\hline short [height] & $k \ddot{o l}-\gamma a d$ & rad-pass & \\
\hline short [length] & $k \ddot{o l}$ & katâ & \\
\hline full & pör & mašt, pər & \\
\hline dirty & $n a s ̌ t$ & lačar & Šahm.=Semn. \\
\hline swim & $\check{s ̌ n n o ~}$ & hasno & \\
\hline to give birth & dârtan & bazâan & See $\$ 5.5$ \\
\hline to swell & vâ dakctan & čaft dakatan & \\
\hline to suck & bösoftan, sök bazвan & bačefessan & \\
\hline to scrape, scratch & barkkkian & barəkessən, bakossan & for Pers. xārāndan \\
\hline $\begin{array}{l}\text { to throw } \\
\text { vesterday }\end{array}$ & jercngian, döm badâan & dəm bədâən & See Tab 7 \\
\hline
\end{tabular}

5.3. The following words exemplify Šahmirzādi words of Mazandarani origins vs. their counterparts in Semnāni and other neighbors. ${ }^{26}$

bâmši 'cat' vs. Semn., Lasg., Sang. RUVÂ, Aft., Lasg., Sorx. NÂzU.

juma 'shirt' vs. Semn. šavi.

bad 'bad' vs. Semn. pis.

26. Small capital letters signify the commonest pronunciation within and across languages. 
xurd 'small' vs. Semn., etc. kasin.

qül 'deaf' vs. Sang. giž, Semn. kar.

šir 'milk' vs. Semn., etc. šat.

dezennun 'tripod' vs. Semn., etc. SEPĀYA, Sang. šepâya.

dovenni 'shoe' vs. Sang., Aft. PEYJÂR, Semn., Sorx., Lasg. LAL(A)KA.

lesek 'snail' vs. Sang. gal-karm, Semn. gāzâlâ.

küp 'straw mat' vs. Sang. sis; all others use Persian hasir.

rik 'gum' vs. Lasg. $z \bar{e}(h)$, Semn., Aft., Sang. GUŠTI DANDONI.

teli 'thorn' vs. Semn., etc. ask.

čâka, čâkepe 'river' (Maz. čukə) vs. RO(D)XÂNA elsewhere in the region.

5.4. Aftari and Sangesari share with Šahmirzādi a pool of Mazandarani words that other neighboring languages do not. The Šahmirzādi-Sangesari-Aftari lexical union can be demonstrated by these words:

sölla 'gutter' agrees with Sang. sölley, vis-à-vis Semn. nâlazóna and similar words in the other dialects of the region.

huz 'basin' is shared by Sangesari and Aftari, and contrasts with xut in other dialects.

sâze 'broom' is shared by Sangesari and Aftari, vs. rīhuna in Semn. and JÂRU in other dialects.

tannir 'tandoor, oven' has similar forms in Sangesari and Aftari, vs. KELA in other dialects.

kalin 'ashes' is similar to Sang., Aft. KALIM, vs. Semn., etc. XAKESTAR.

kâp, kâb 'heel' is shared by Sangesari and Aftari, vs. Semn., etc. PÂŠNE.

vak 'frog' is shared by Sangesari and Aftari, vs. Semn., etc. VAZAQ.

jöma 'Friday', also in Aftari; Semn., etc. uyna (<ādīna).

katâr 'chin', also in Sangesari, vs. $\breve{c} A(K U) N E$, etc. in other dialects.

vasni 'co-wife', also in Aftari vs. Semn. dohamin jan(n)ia and the likes in most other dialects.

qöšâr 'pressure'; cf. Sangesari and Firuzkuhi qešâr, as opposed to Sorx. fešâr and Lasg. šexâr.

5.5. Areal features. Šahmirzādi's adaptation to the neighboring languages of Semnān zone can be illustrated in the following words.

$k o t a(k)$ 'child' agrees with $k^{u}$ ota in Sangesari and contrasts with vačə in Mazandarani and the rest of the Semnān area.

lülü/lüli (Žuk. lölü) 'dress, clothes’ has similar forms in Sangesari and Aftari, vs. Semn., Sorx., Lasg. HALA.

dâr- : dârt-/dâšt- 'give birth to', also in Sangesari.

miš 'mouse'; cf. Semn. müš and the likes in other dialects vs. Maz. gal.

maryija 'sparrow', similar to Aft., Semn., Sorx., Sang. MAR(GU)JA vs. Maz. MIčKÂ.

$x u z$ 'walnut', corresponds to Sorx. hüž, Sang. yuz, vs. Maz. âyuz.

vašir 'unsalted, tasteless', ${ }^{27}$ with similar forms in Semn., Lasg., Sorx., Sang. vs. Maz.

be-nəmək. 
huften "weave" (along with vâftən), cf. Semn. hönattion, Sorx. hâvâfton, Lasg. òveton, Aft. hovaton, Sang. hövetan, vs. Maz. bofton.

xošten 'self', also used in Semnāni proper, as xošton, and its varieties throughout the region: Semn. (also) huštara, Sorx. hušterâ, Lasg. ušterâ, Sang. eštere. Note the diffusion of this type into southern and eastern frontiers of Mazandarani, as xaštən, contrasting with common Mazandarani $̌$ e.

An instance of hybridization across language zones is Šahmirzādi čitikâ 'chicken', standing halfway between Maz. čin(n)ekâ and Semn. čuta, Aftari čute.

5.6. Idiosyncrasy. I have come across several words in Šahmirzādi that are neither Mazandarani nor Semnāni. Most noticeable is mahin 'big', which contrasts with both Maz. gat and Semn., Sorx., Aft., Sang. masin (see Table 7). The Šahmirzādi form occurs also in archaic New Persian, thus could have spread out westward from Khorasan, although my attempts to find this word in the current Khorasani dialects of Persian were in vain. The only occurrence of mahin I could find in Mazandarani documents is in a verse attributed to Amir Pāzvāri, collected orally in the nineteenth century: man botparastun-râ hama mahin bum "I would be the biggest of idol worshippers" (Dorn 1860: 95); this incidence however seems to be mere archaism.

Other possible characteristic Šahmirzādi words are šarša 'rock'; zököt 'elbow', vs. Maz. aleskin, Semn. etc. MARAKA. Note also the circumlocution döm-darâz 'snake', lit. 'long-tail', which is an avoidance euphemism based on the belief that the subject can be invoked when its name is uttered.

\section{LINGUISTIC POSITION}

What warrants a detailed areal study of Šahmirzādi, as a Caspian variety, is its geographic position in a fairly small linguistic zone that hosts other Iranian linguistic types genetically distant from the Caspian language family. Besides Šahmirzādi, there are at least three language types spoken in Semnān district. While Semnāni proper and Sangesari can be classified as isolates within the Northwest Iranian family, the status of Sorxa'i, Lāsgerdi, and Aftari as distinct languages or dialects of the same language is not yet established due to paucity of data (cf. Morgenstierne 1960, Lecoq 1989). Different language types notwithstanding, there can be seen a certain degree of convergence in the area that justifies the areal designation Semnān Sprachbund. Another designation I have used for this areal union is Komisenian, or Kumeši (Borjian 2008), after the historical name of Semnān province, to avoid confusion between the Sprachbund and Semnāni proper.

The striking similarities of Šahmirzādi with Mazandarani proper, as shown in this study, leave little doubt that Šahmirzādi has branched out from the bulk of Mazandarani, but a chronology is difficult to establish, given the lack of an historical record on Šahmirzād, let alone its vernacular. It is also not reasonable to arrive at a date of separation based on comparative linguistic analyses, for although Šahmirzādi is a linguistic outlier, it has always been in contact with Mazandarani, across the Alborz chain, through trade and seasonal migrations, a condition that must have decelerated the process of divergence.

Now let us consider the question, whether Šahmirzādi is a variety of Mazandarani or else has drifted away far enough from it to be classified a separate language directly under the Caspian family of languages? Existing opinions differ on this matter. While Šahmirzādi has been viewed as a distinct variety of the Mazandarani language by certain scholars (Rastorgueva and Edel'man 1982: 450; Lecoq 1989: 490), Ethnologue (2017) classifies Šahmirzādi (with language identifier srz) as a subgroup of the Caspian Language family, distinct from both Gilaki and Mazandarani, while Glottolog (2017, which treats all language varieties as "Lan- 
guoids") classifies Caspian into Gilaki-Rudbari and Mazanderani-Shahmirzadi, and assigns shah1253 as the code for Šahmirzādi. Donald Stilo, an authority on the typology of Iranian languages, holds the view that there might be enough features that justify a separate classification for Šahmirzādi within the Caspian family (pers. comm.; see also Stilo 1981). Moreover, in a recent typological study of the language varieties surrounding Mazandarani proper, which incorporated ten grammatical features, Šahmirzādi differed from Mazandarani proper only in one feature, the imperfect (Borjian 2013b, Table 7; see also Borjian 2013a).

The imperfect is indeed the most salient morphological split of Šahmirzādi from its original speech community. The contrast, as shown under $\S 4.3 .1$, leads to physiognomic differences such as Šahm. mavâfta vs. Maz. boftz 'he would weave', in which Šahmirzādi incorporates the durative prefix $m V$-. This marker, which results in structural asymmetry between the past and present in Šahmirzādi, could have been borrowed from either Semnāni or Persian; the marker in all likelihood originated in early New Persian through grammaticalization of the adverb hame.$^{28}$ The functional item $m V$-, formidable as it looks, has proved to be highly contagious as it has permeated, in a span of less than a millennium, not only Semnāni but also Tāti, another Northwest Iranian language group genetically remote from Persian. As for Šahmirzādi, the marker may have been borrowed from Persian, the lingua franca of Semnān district.

Aside from the imperfect marker, another remarkable morphological feature that sets Šahmirzādi apart from Mazandarani is the preverb on the present (§4.2.1). In terms of phonology, the fronting of the round back vowels (\$2.2.8), characteristic of the Semnān area but not Mazandarani proper, plays a far less important role in separating Šahmirzādi from its kin. Subsequently, phonological and morphological changes on the whole have not been profound enough to trigger syntactic changes.

On the lexis front, a broad comparative study of Šahmirzādi vocabulary is yet to emerge. The comparative basic vocabulary analysis above (\$5.2) reveals that the lexical inventory of Šahmirzādi is at minimum in 85 percent agreement with Mazandarani, while some lexical leveling within the Semnān region is at work (§5.5), and there are striking idiosyncrasies ( $\$ 5.6)$ to be explained by spreading out our areal net.

Returning to the question of the language or dialect status, we may draw a comparison between Šahmirzādi and the vernacular of Kalārestāq, which is spoken on the west of the Čâlus river, and is classified by Stilo (2001) as a Central Caspian language different from both Gilaki and Mazandarani. In morphosyntax, Kalārestāqi shows more contrastive features with Mazandarani proper (Borjian 2010) than Šahmirzādi does, but certainly not in vocabulary, as far as it can be judged impressionistically in this preliminary survey. A detailed study of the Caspian family will make things clearer. Also wanting is a study of mutual intelligibility between Šahmirzādi and Mazandarani proper.

A classification can be defined and supported by linguistic data, but the status of a language variety as a "language" vs. "dialect" is relative and is almost always ultimately socially rather than linguistically defined, even if linguistic factors are important as well. Extralinguistic factors, such as ethnic and linguistic identities, are important in this regard. Šahmirzādis refer to themselves as gelak and to their language as gelaki "Caspian," as do the people of Mazandaran and Gilan. Many speakers of Šahmirzādi believe that their vernacular is merely a Mazandarani variety (close to the varieties spoken in Šăhi and Bābol but not as close to those of Firuzkuh and Sāri) and their culture is far closer to Mazandaran than their immediate neighbors. Recently Šahmirzādis have filed an official appeal on the grounds 
of "culture and language" for their district to join the province of Mazandaran (Fars New Agency 2003).

It would also be interesting, if data were available, to compare Šahmirzādi with the Mazandarani dialects immediately to its north, to find out whether it is a true insular Caspian outlier or if there is some areal continuity. Further northeast in Parvar, as far as the poems of Gudarzi (2009) reveal, the dialect is not Šahmirzādi but close to the Mazandarani varieties spoken across the Alborz ridge in Pāji and Sangedeh, ${ }^{29}$ the southernmost villages of the Dodānga, which constitute the uplands of Sāri (Fig. 1). The data are scanty, but already show certain shared features, such as xošten $(\S \S 3.3 .2,5.5)$, which is found also in Firuzkuhi. My informants told me that Šahmirzād used to have mutual trading with communities immediately to the north via mountainous trails as well as with Firuzkuh along the caravan road via Aftar and the Bašm pass.

Another venue to consider in a typological study is along the south Alborz belt that stretches from Semnān westward. Take for instance the Šahmirzādi word bušu 'go!' which is shared by the varieties spoken in the southern foothills of Alborz, ${ }^{30}$ from as far east as Ṭāleqān down to Šemirān, and further east to Damāvand and the Semnān area, while Mazandarani proper, i.e., the varieties spoken on the east of Čălus river and north of the AntiAlborz, use the irregular form bur exclusively. This wave-like distribution poses yet another challenge in the provenance and linguistic position of Šahmirzādi.

29. On which I have limited field notes.

30. Borjian 2013b.

\section{ABBREVIATIONS}

Small capital letters signify the commonest pronunciation within and across languages.

Colon (:) stands between the present and past stems of verbs.

Aft. Aftari

Chris. Christensen

Dabir. Dabir-Moqaddam

Ir. Iranian

Kalb. Kalbāsi

Lasg. Lāsgerdi

Maz. Mazandarani

Morgen. Morgenstierne

Pers. Persian

Pur. Purkarim

pl. plural

Sang. Sangesari

Semn. Semnāni

sg. singular

Sorx. Sorxa'i

Sotu. Sotuda

Šahm. Šahmirzādi

Žuk. Žukovskij 


\section{REFERENCES}

Anonby, E. J. 2003. Update on Luri: How Many Languages? Journal of the Royal Asiatic Society 13.2: 171-97.

Borjian, Habib. 2005. Šenāsa-ye fe`1 dar māzandarāni-e šarqi. Guyeš-šenâsi 1.3: 13-19. 2008. The Komisenian Dialect of Aftar. Archiv Orientální 76.3: 379-416.

2010. Kalārestāq. In Encyclopaedia Iranica XV/4. Pp. 367-73. New York: Columbia Univ. 2013a. The Tabaroid Dialects of South-Central Alborz. Acta Orientalia 66.4: 427-41.

2013b. Perso-Tabaric Dialects in the Language Transition Zone Bordering Mazandaran. Studia Iranica 42.2: 195-225.

Cheung, Johnny. 2007. Etymological Dictionary of the Iranian Verb. Leiden: Brill.

Christensen, Arthur. 1935. Contribution à la dialectologie Iranienne, vol. 2: Dialects de la région Sèmnān: sourkhéî, lāsguerdī, sängesärī, et chämerzådī. Copenhagen: Andr. Høst \& Søn.

Dabir-Moqaddam, Moḥammad. 2014. Radašenâsi-e zabānhā-ye irāni. 2 vols. Tehran: Samt.

Dorn, B. A. 1860. Ketāb-e Kanz al-asrār-e Māzandarāni: Beiträge zur Kenntnis der Iranischen sprachen, vol. 1: Masandaranische Sprache. St. Petersburg: Kaiserlichen Akademie der Wissenschaften.

Ethnologue: Languages of the World, 20th ed. 2017. Dallas: SIL International. Online at http://www. ethnologue.com/language/srz.

Fars News Agency (Xabargozāri-e Fārs). 2003. Taqāżā-ye šahmirzādihā barấye elhāā-e be Māzandarān. 19 Šahrivar 1392 Š./9 September 2003; at farsnews.com/newstext.php?nn=13920618000832.

Glottolog 3.1. 2017. Jena: Max Planck Institute for the Science of Human History. Online at: http:// glottolog.org/resource/languoid/id/shah1253.

Gudarzi, M.-R. 2009. Sut o nâješ: Sorudahā o tarānahā-ye buni-e Parvar. Semnān: Hablerud.

Hasandust, M. 2010. Farhang-e taṭbiqi-mowżu $i$-e zabānhā o guyešhā-ye irāni-e now. 2 vols. Tehran: Farhangestān.

Kalbāsi, Irān. 2009. Farhang-e towșifi-e gunahā-ye zabāni-e Irān. Tehran: Pažuhešgāh-e 'Olum-e Ensāni.

Kolbitsch, A. 2008. Unpublished audiotape eliciting a 227-item basic vocabulary from two Šahmirzādi speakers, Šahmirzād.

Lazard, Gilbert. 1963. La langue des plus anciens monuments de la prose persane. Paris: Klincksieck. 1970. Etude quantitative de l'évolution d'un morphème: La postposition râ en persan. In Mélanges Marcel Cohen, ed. D. Cohen. Pp. 381-88. Berlin: De Gruyter.

Lecoq, P. 1989. Les dialectes caspiens et les dialectes du nord-ouest de l'Iran. In Compendium linguarum iranicarum, ed. Rüdiger Schmitt. Pp. 296-312. Wiesbaden: Reichert.

Morgenstierne, Georg. 1960. Stray Notes on Persian Dialects. Norsk Tidsskrift for Sprogvidenskap 19: $72-140$.

Perry, John R. 1996. Persian in the Safavid Period: Sketch for an état de langue. In Safavid Persia: The History and Politics of an Islamic Society, ed. C. Melville. Pp. 269-83. London: I. B. Tauris \& Company.

Rastorgueva, V. S., and D. I. Èdel'man. 1982. Prikaspijskie jazyki: giljanskij, mazanderanskij (s dialektami Šemerzadi i Velatru). In Osnovy iranskovo Yazykoznanija, vol. 3: Novoirankie Yazyki: Zapadnaja gruppa, prikaspijskie jazyki, ed. V. S. Rastorgueva. Pp. 447-54. Moscow: Soviet Academy of Science.

Skjærvø, Prods Oktor. 2009. Middle West Iranian. In The Iranian Languages, ed. Gernot Windfuhr. Pp. 196-277. London: Routledge.

Sotuda, Manučehr. 1963. Farhang-e semnāni, sorxa'i, lāsgerdi, sangesari, šahmirzādi. Tehran: Tehran Univ. Press. (Rpt. 1977.)

Stilo, Donald. 1981. The Tati Language Group in the Sociolinguistic Context of Northwestern Iran and Transcaucasia. Iranian Studies 14: 137-87. 2001. Gilān x. Languages. In Encyclopaedia Iranica, vol. 10, fasc. 6. Pp. 660-68. New York: Columbia Univ. 
Windfuhr, Gernot, and John R. Perry. Persian and Tajik. 2009. In The Iranian Languages, ed. Gernot Windfuhr. Pp. 416-44. London: Routledge.

Yoshie, Satoko. 1996. The Säri Dialect. Tokyo: Institute for the Study of Languages and Cultures of Asia and Africa.

Žukovskij, Valentin A. 1922. Materialy dlija izučenija persidskix narečij, vol. 2. Petrograd: Russian Academy of Science. 